\title{
MRS Committees Focus on Expansion, Awareness, Excellence in 1990
}

Chairs of the 12 standing committees of the Materials Research Society have announced their goals and focus for 1990 , emphasizing a common theme of expanded services with a continued commitment to technical excellence. Increasing awareness about MRS and its activities among the general public and government policymakers as well as the broad international materials community is also a key objective. Demonstrating long-range vision for the Society, several Committees are exploring exciting new dimensions of information and service to the materials research community. For further information on specific activities of these MRS committees, contact the committee chairs identified below.

\section{Awards Committee}

Chair, J. Murray Gibson, AT\&T Bell Laboratories, 600 Mountain Avenue, Murray Hill, NJ 07974; telephone (201) 582-5952; fax (201) 582-2685.

The Awards Committee oversees the Society's role in recognizing outstanding achievements in materials science. This year the Council approved the addition of two new awards-Outstanding Young Investigator and MRS Medalist. The complete MRS awards portfolio consists of the following:

- The Von Hippel Award, the most prestigious award given by MRS. Nominations must be received by July 1 and a special subcommittee works with the MRS Council to identify the recipient.

- Graduate Student Awards, given at both the Spring and Fall Meetings. Following an experimental procedure last year, the Student Awards Subcommittee plans to evaluate students' oral presentations at the meeting to select award winners from preselected finalists.

- MRS Medal, given in recognition of outstanding recent achievements in materials research. Nominations will be due by July 1 of the year in which the award is to be given and will be administered by a special subcommittee.

- Outstanding Young Investigator Award, given in recognition of exceptional promise as a developing leader in the materials area. A special subcommittee will oversee selection from nominations due by November 1 preceding the year of presentation. This award will normally be presented at the Spring Meeting.

Editor's Note: For details on these awards, see the March 1990 MRS BULLETIN, p. 82.

\section{Continuing Education Committee}

Chair, Carol M. Jantzen, Westinghouse Savannah River Co., Savannah River Site, Building 773A, Aiken, SC 29808; telephone (803) 725-2374; fax (803) 725-4704.

As part of the long-term strategy for future growth and development, the Continuing Education Committee recently adopted a Long-Range Mission Plan for the Short Course Program. Its essential goals are to:

- Provide a service to MRS members and the materials science community by offering quality and relevant topical courses which complement and enhance the technical program of MRS meetings and the image of MRS within the materials science community;

- Develop an evolving multidisciplinary program by presenting new topical courses, while maintaining a balanced and innovative educational program;

- Develop and critically evaluate evolving education forums such as on-site programs, stand-alone programs, video courses, and educational resource materials for universities and the materials science community; and

- Investigate creative avenues to further enhance the Continuing Education Program and image.

Based on the Long-Range Mission Plan, the Committee developed priorities for the Short Course Program, which is under the direction of Short Course Manager Vivienne Harwood Mattox. These priorities are to:

- Present short courses at MRS meetings as a dynamic complementary forum for technical information exchange;

- Present short courses for industry and other requesting organizations through the On-Site Program;

- Develop stand-alone short course programs (independent of MRS meetings) with MRS Chapters and Sections;

- Develop educational materials for grassroots materials science education and assist teachers in motivating high school students;

- Together with the Academic Affairs Committee, develop strategies to assist the academic community by providing educational resources such as videotapes and other materials; and

- Ensure that universities are aware of the opportunities provided by the Short Course Program scholarship program.

In 1990 the Continuing Education Committee is presenting a number of new courses. Seven new courses are being pre-

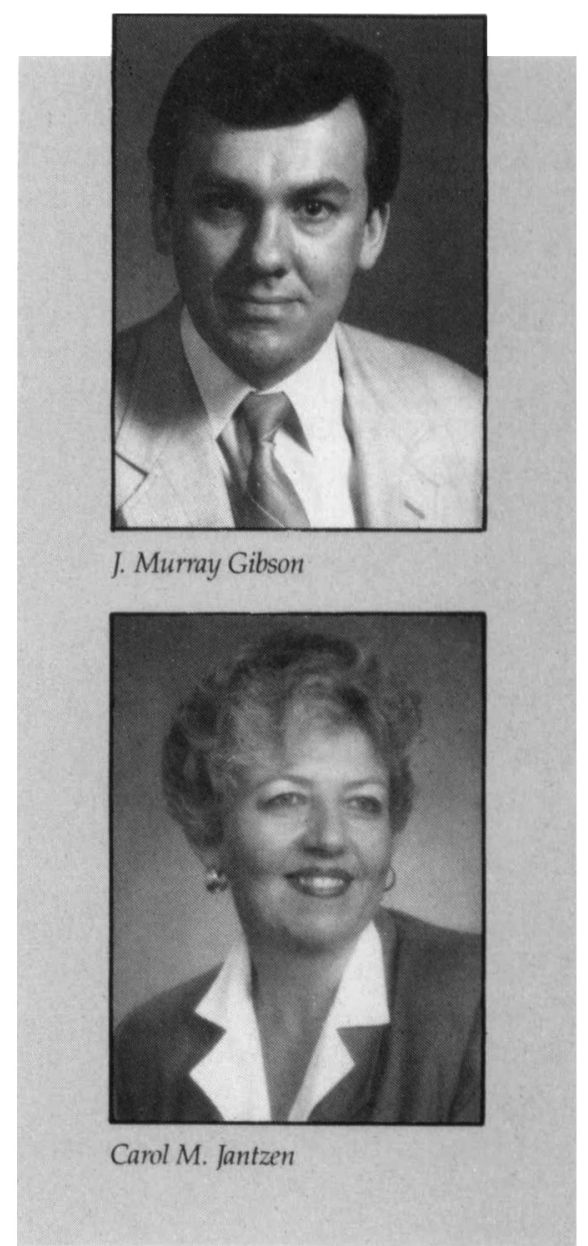

sented at the 1990 MRS Spring Meeting i the areas of ceramics, electronic material and materials processing. Five addition: courses are under review or developmes for presentation at the Fall Meeting. A ne' course on Environmental, Health, an Safety Aspects of Semiconductor Manı facturing has been developed for present tion at an On-Site Program of nine MR courses to be hosted by the Massachuset. Microelectronics Center in Westborough, Massachusetts in June. (This course was developed at the request of the host organization.) The development of new course topics at the specific request of industry is considered to be of prime interest and importance to the Committee.

The On-Site Program is one of the most rewarding offshoots of the Short Course Program, since most on-site presentations occur as a result of satisfied course attendees at MRS meetings, who ask their management to bring the course to their 


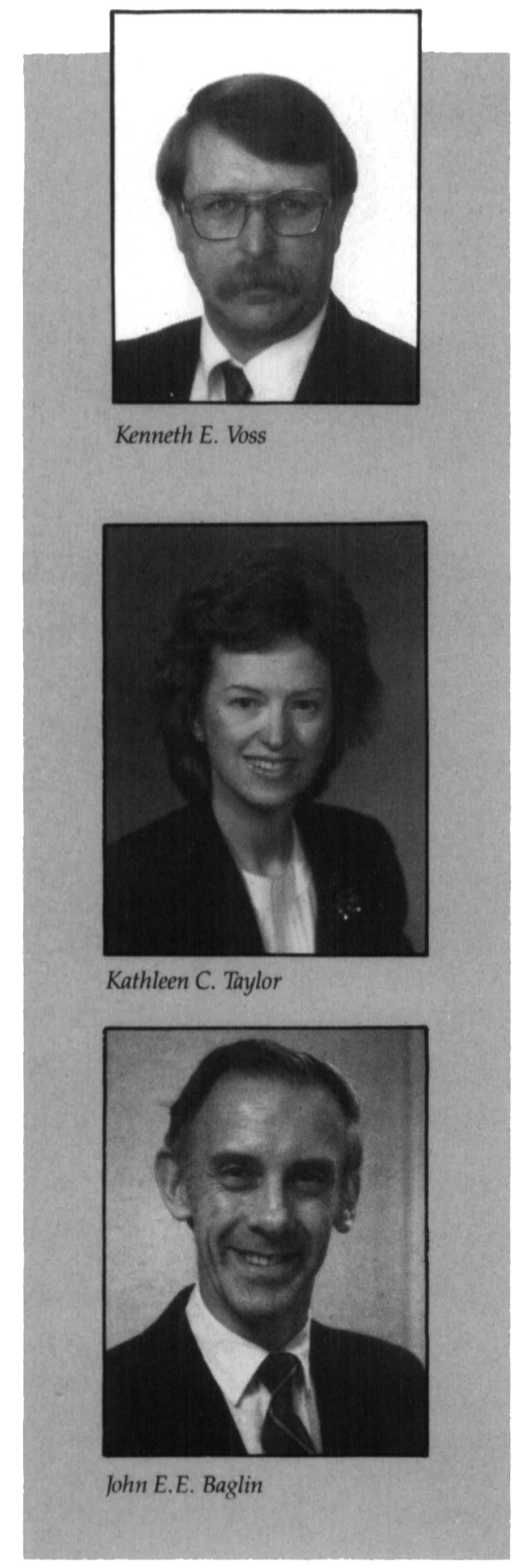

geographical site so that their colleagues can benefit.

In 1989 the Committee took the first step in developing videotapes to enhance live lecture-style short courses by videotaping practical demonstrations of Rutherford backscattering and Auger spectroscopy laboratory techniques. If this pilot project is successful, the Committee plans to expand the use of videotapes to enhance the live
Short Course Program. In the future, upgraded versions of these tapes may be made available to MRS Chapters and professors in other universities involved in teaching surface and thin film analysis, as part of the Committee's plan to assist the materials science academic community.

The potential for using videotapes to develop educational materials at the precollege level for grassroots materials science education is also being explored. A new subcommittee is being formed to spearhead the Committee's efforts in grassroots materials science education. There is considerable interest within the materials science community regarding the quality of science education in the United States at all levels-pre-school through high school-and the Continuing Education Committee plans to take an active role in MRS efforts in this area.

\section{Corporate Participation Committee}

Chair, Kenneth E. Voss, Engelhard Corporation, Menlo Park, CN 28, Edison, NJ 08818; telephone (201) 321-5146; fax (201) 321-0334.

The Corporate Participation Committee is the interface between MRS and its Corporate Affiliates, who currently number over 180 . The Corporate Affiliates play a vital role in MRS by ensuring that the Society's technical programs respond to the interests of the corporate materials research community. The Committee is responsible for keeping the Corporate Affiliates abreast of MRS activities, for seeking advice on topics to be addressed at its meetings, and for broadening the base of support for MRS and its activities in the corporate sector.

The 1990 Committee will continue to concentrate on increased Affiliate participation. This will include those companies exhibiting at the Spring and Fall Meetings. In addition to the efforts to increase domestic participation, a liaison has been established to focus on the international level.

\section{External Affairs Committee}

Chair, Kathleen C. Taylor, General Motors Research Laboratories, Physical Chemistry Department, Warren, MI 48090; telephone (313) 986-2010; fax (313) 986-8697.

The MRS External Affairs Committee operates through three subcommittees: Domestic Activities, Public Affairs, and International Affairs. The Domestic Activities Subcommittee, chaired by G.E. Pike, Sandia National Laboratories, is responsible for implementing the MRS Affiliated Organization program. In addition, this Subcommittee handles correspondence with other U.S.-based technical societies, including co-sponsorships and endorsements.

The Public Affairs Subcommittee, chaired by E.N. Kaufmann, Argonne National Laboratory, is responsible for administering MRS public affairs activities at the request of the MRS Council and Executive Committee. This year the Subcommittee is charged with establishing an MRS office in Washington, DC. As a first step an ad hoc implementation task group was formed which will advise MRS Council on the most appropriate mechanisms to use to pursue activities on behalf of MRS which are related to information flow to and from federal agencies and other sources. Another task of the Public Affairs Subcommittee will be to represent MRS at meetings of the Ad Hoc Committee on a "Materials Institute Concept."

The International Relations Subcommittee, chaired by C.W. White, Oak Ridge National Laboratory, is responsible for interfacing with all international MRS-type organizations.

In addition to these subcommittee activities, the External Affairs Committee handles requests from government institutions for information or assistance. Occasionally the Committee sponsors special events at MRS meetings (e.g., panels or discussion groups) which serve the entire materials research community. In $1990 \mathrm{em}$ phasis will be given to assisting with the implementation of the NAS study, Materials Science and Engineering for the 1990s.

\section{Long Range Planning Committee}

Chair, John E.E. Baglin, IBM Almaden Research Center, K34/802, 650 Harry Road, San Jose, CA 95120-6099; telephone (408) 927-2280; fax (408) 927-2100.

The Long Range Planning Committee began in 1989 to develop a strategic plan for the coming decade of MRS growth and activity. It was felt important that such a plan should be visionary and ambitious, leaving scope for the kind of innovation that has brought MRS to its present state of prosperity and excitement. The plan should first ask, "Where would we like MRS to be positioned in the environment that we predict for the year 2000?" Having established critical goals describing all aspects of our present and future activity, and established a consensus within the Society on these goals, we should then go to the second stage of describing the positive actions needed to reach those goals. The entire plan would then present a coordinated framework within which to make future policy decisions and resource commitments, begin new activities, and implement new long-term strategies. 
At the 1989 MRS Fall Meeting, the Committee reviewed the first part of a "Long Term Positioning and Goals" study paper prepared by John Baglin, IBM Almaden; Gordon Pike, Sandia National Laboratories; and Kathy Taylor, General Motors Research Laboratories, with assistance from several other Committee members. Subsequently, it was submitted for detailed comments and suggestions to a broad spectrum of MRS activists, including Councillors, Meeting Chairs, Committee Chairs, and staff. Their thoughtful responses constituted key material for preparing the completed "Positioning and Goals" paper, which was reviewed by Council at the 1990 MRS Spring Meeting. The task before the Committee now is to prepare the "Implementation and Strategy" part of the plan for review and discussion at the 1990 Fall Meeting; this work is currently progressing steadily.

The Committee would welcome input to this process from all interested MRS members. Members wishing to receive a copy of the "Long Term Positioning and Goals" book should contact John Baglin.

\section{Membership Committee}

Chair, Michael J. Kelley, Engineering Technology Laboratory, E.I. du Pont de Nemours \& Co., Inc., P.O. Box 80304, Wilmington, DE 19880-0304; telephone (302) 695-3829; fax (302) 695-2504.

The Membership Committee expects to focus on three areas this year: local Sections, member communications, and nonmember communications.

We will work out ways the Society can act vigorously to help regularly meeting local Sections to start up and prosper, becoming the grassroots of MRS. We expect these ways may include local Section "how-to" workshops, resources for programming, and resources for beginning operation.

Member communications will include development of the successful and valuable annual membership directory and ways to facilitate communications with Headquarters. Last year the Committee made an extensive survey of membership needs, and these findings will be translated into an agenda for action.

Nonmember communications means looking for new and effective ways to tell others about the benefits MRS offers. The goal is not growth for growth's sake, but rather seeking to assure that all those who can profit from association with the Society are clearly invited to do so.

\section{Nominating Committee}

Chair, R.P.H. Chang, Northwestern University, Department of Materials Science and Engineering, 2145 Sheridan Road, Evanston, IL 60208; telephone (708) 4913598; fax (708) 491-4181.

The Nominating Committee is responsible for constructing a well-balanced slate of candidates for the positions of Officer or Councillor of MRS, a slate which Council must endorse before the annual election is held during the summer. It is always this Committee's goal to seek excellent, enthusiastic and capable people, and also to maintain within the Council and Executive Committee a healthy representation of the disciplines of our members and to maintain sound representation from academia, industries, and government laboratories.

\section{Program Committee}

Chair, Paul S. Peercy, Sandia National Laboratories, Div. 1140, P.O. Box 5800, Albuquerque, NM 87185; telephone (505) 844-4309; fax (505) 846-2009.

The MRS Program Committee provides guidance and coordination for technical programming. In a broader sense it is the Program Committee's responsibility to ensure that the "MRS Spirit"-the exciting atmosphere and interdisciplinary environment of technical meetings-is preserved and enhanced. Clearly the quality of our technical meetings must remain the Society's highest priority. It is only by maintaining exceptional quality that we can enlist the involvement of the most outstanding people; ultimately it is the people who make the difference.

The Program Committee is composed of appointed members, the MRS First Vice President, and the Spring and Fall Meeting Chairs for the current and immediate past two years. The Committee has previously focused on reviewing the technical symposia proposed by the Meeting Chairs. The Committee also serves as a focal point for the input of new ideas for symposia and for concerns about program coverage. The innovation for the meetings over the years has really come from the Meeting Chairs with input from the membership. It is essential that the Meeting Chairs continue to provide the technical vitality for the MRS meetings and that the Program Committee do everything it can to nourish that process.

The entire process of establishing the final program for our Spring and Fall Meetings requires the input of many people, and the Program Committee is at the heart of this process. In order to provide more effective and timely feedback to Meeting Chairs, a Program Development Subcommittee was recently established and is currently chaired by Julia Phillips, AT\&T Bell Laboratories. This Subcommittee reviews the proposed program with Meeting

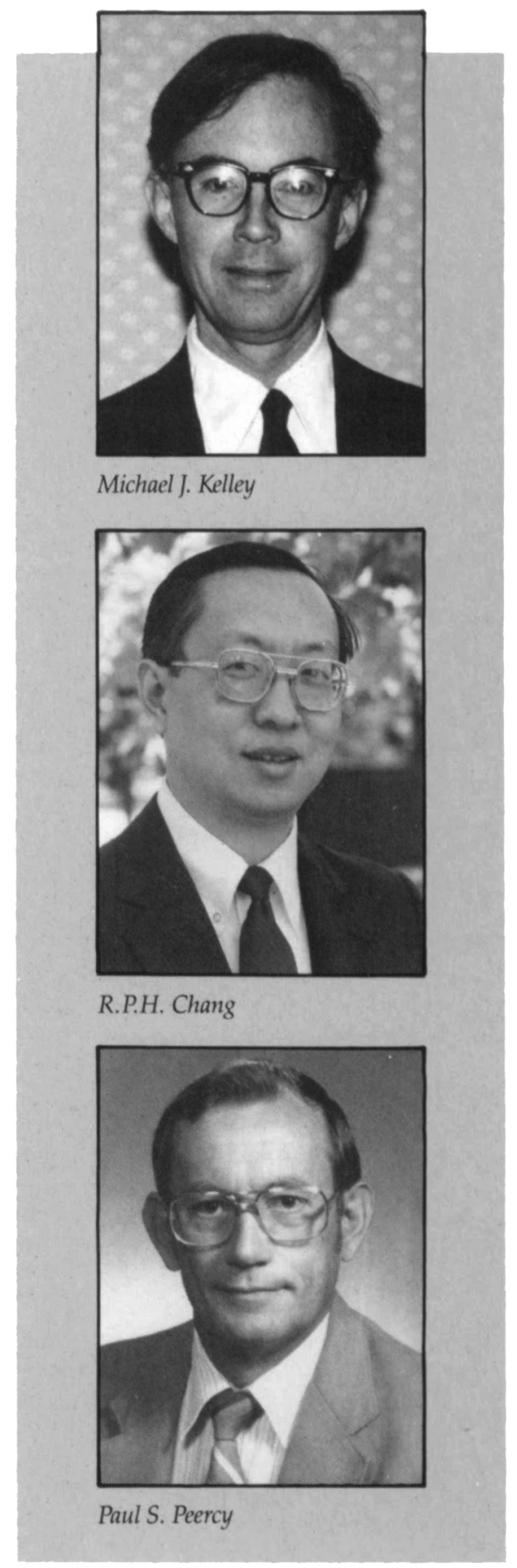

Chairs about 14 months in advance of the meeting, with special consideration to program balance, coverage of major constituencies, and potential problems or conflicts. For example, this past February the Subcommittee met with the 1991 Spring Meeting. Chairs by conference call to review the tentative program and address questions in advance of the full Program Committee meeting. This procedure allows program adjustments at an early stage. I am proud 

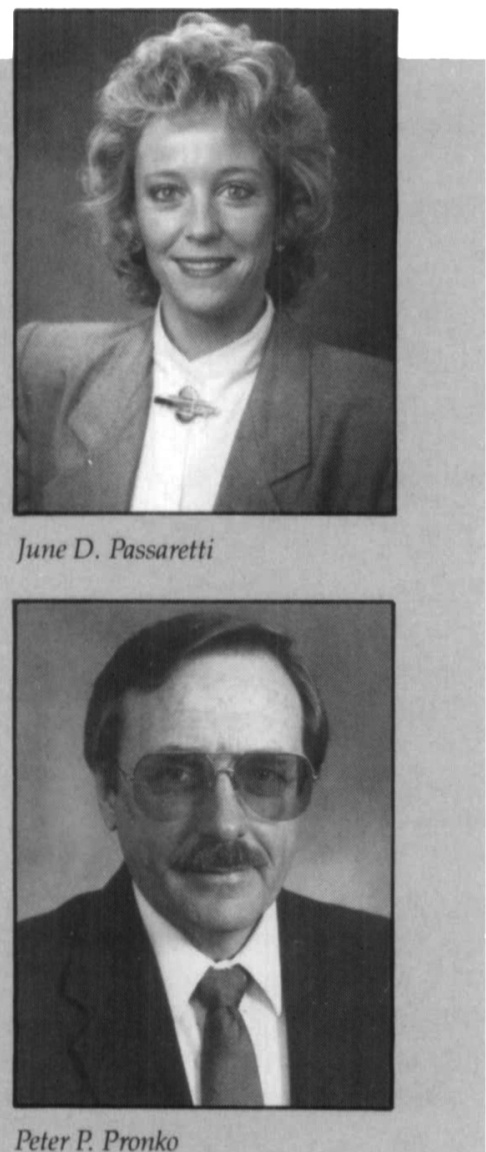

of the fact that MRS has a balanced technical program in place 12 months in advance of the meeting. In addition, symposia covering exciting new developments can be incorporated as needed. This strong but flexible programming is something few other societies achieve.

The Program Committee is actively working to develop high quality, coordinated programs for the 1991 Spring and Fall Meetings. We are also continuing to look for better ways to ensure that we meet the programmatic needs of our constituencies. For example, we are planning topical conferences in addition to the Spring and Fall Meetings. Major MRS sponsored or co-sponsored topical meetings include the Second International Conference on Electronic Materials (ICEM II) September 17-19, 1990 , in Newark, NJ; the International Ion Beam Modification of Materials Conference (IBMM-90) September 9-14, 1990 in Knoxville, TN; the Second International Conference on New Diamond Sciences and Technology, September 23-27, Crystal City, VA; and a Washington, DC Meeting, February 28-March 1, 1991, with symposia on "Superconducting Thin Films for Electronic Applications" and "The Science
Behind Semiconductor Processing: Advances in Plasma and CVD Research." The Washington meeting, which will be held in conjunction with the Spring Forum of the Solid State Sciences Committee of the $\mathrm{Na}$ tional Research Council, is co-sponsored by at least six major technical societies and will not only provide participants a technical forum but will also give them access to the Washington community.

\section{Public Relations and Publicity Committee}

Chair, June D. Passaretti, Pfizer Minerals Research Center, 9 Highland Avenue, Bethlehem, PA 18017; telephone (215) 8613431; fax (215) 861-3412.

The Public Relations and Publicity Committee was established in 1984 to publicize Society activities to members through the MRS BULLETIN, and to nonmembers through articles and calendar entries in appropriate journals. Although the Committee still performs these functions, its role in the Society has grown in response to the increased membership and recognition of the Society's meetings as a major forum for materials research.

Over the next year, this Committee will focus on obtaining greater recognition for MRS, both in the scientific community and among members of the general public, as an organization that is the vital link between fundamental research and the technological advances that benefit humanity. Publicity about the Society's activities contributes not only to increased recognition of MRS, but to greater public awareness and knowledge about the value of materials research. This, in turn, can have a positive impact on, among other things, meeting attendance, membership, funding for scientific programs, and education.

The Committee works with MRS members and the media to accomplish these tasks. For example, for each Spring and Fall Meeting, speakers are nominated by symposium organizers to write lay language abstracts of their presentations for inclusion in the MRS press kit. In addition, a number of the abstracts are rewritten with the authors' permission as a press release for distribution before and during the meeting. Many of these abstracts and releases become feature articles in both consumer and technical journals, the science sections of major newspapers, and on occasion, the television news.

The current Committee, composed of member volunteers who serve for a threeyear period, represent the East and West Coasts and Europe. Starting in 1990, the Committee also has support of a half-time public relations manager at MRS Headquarters, who will serve as liaison between members, the Committee and the press; coordinate publicity efforts for the meetings; ensure continuity and preservation of long-range contacts with the press and the technical community; and enable MRS to reply to the increased amount of press inquiries that occur year-round.

The Public Relations and Publicity Committee will continue to facilitate the interaction of the Society and its members with the scientific and public media to further the understanding of and support for research into advanced materials.

\section{Publications Committee}

Chair, Peter P. Pronko, Universal Energy Systems, Inc., 4401 Dayton-Xenia Road, Dayton, $\mathrm{OH} 45432$; telephone (513) 4266900; fax (513) 426-5718.

The Publications Committee oversees the quality of the existing MRS publishing program, which includes books, Joumal of Materials Research, and the MRS BULLETIN, as well as develops ideas for new publications that serve the needs of the materials research community.

Several milestones reached in late 1989 in the book publishing have laid the groundwork for new opportunities beginning in 1990. First, MRS published its first monograph, Atom Probe Microanalysis: Principles and Applications to Materials Problems; and second, for the first time, annual sales of books and videotapes exceeded $\$ 1$ million. As a result of these achievements, the Committee will be exploring opportunities for other book projects, including a review book series, during 1990.

Joumal of Materials Research, which has continued to grow rapidly in editorial scope and readership, is being published monthly for the first time in 1990 . In recognition of its full five years of publication at the conclusion of the year, a Five-Year $\mathrm{Cu}$ mulative Index is being developed. Also under way this year is a major marketing study of $J M R$ to help determine how best to sustain its continued growth and usefulness to the research community.

The MRS BULLETIN has received wide acclaim for its technical focus issues and features that span a wide range of topics of interest to research, industry and education. This year the BULLETIN will include in-depth overviews of topics such as magnetic materials, optical materials, multilayered materials, materials for vacuum, interfaces, neutron scattering, and by popular request, updates on high-temperature superconductors and materials education. The Committee will continue to monitor the direction of the BULLETIN to ensure it is responsive to the needs of the members and other materials professionals worldwide.

MIRIS 


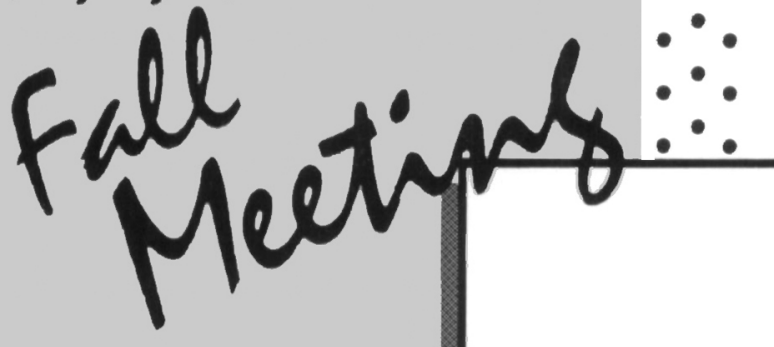

November 26 December 1 , 1990

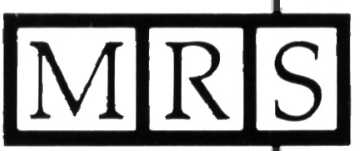

MATERIALS RESEARCH SOCIETY
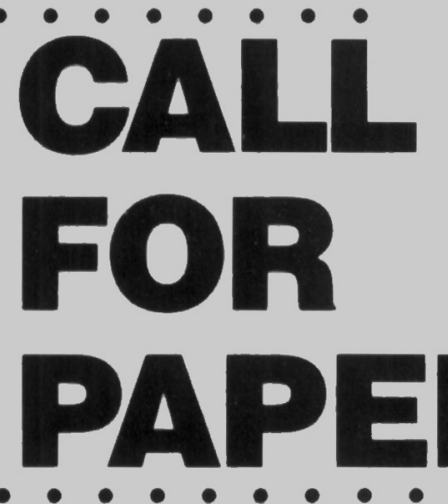

MEETING CHAIRS

Robert Hull

AT\&T Bell Laboratories

Room 1E-345

600 Mountain Avenue

Murray Hill, NJ 07974

TEL: (201) 582-6455

FAX: (201) 582-3901

Gregory J. McCarthy

North Dakota State University

Department of Chemistry

Fargo, ND 58105

TEL: (701) 237-7193

FAX: (701) 237-8831

Frans Spaepen

Harvard University

Pierce Hall

29 Oxford Street

Cambridge, MA 02138

TEL: (617) 495-3760

FAX: (617) 495-9837
SYMPOSIUM A: SURFACE CHEMISTRY AND BEAM-SOLID INTERACTIONS Harry Atwater, California Institute of Technology, (818) 356-2197, FAX (818) 356-2944, haa@daedalus.caltech.edu; Frances A. Houle, IBM Almaden Research Center, (408) 927-2420, FAX (408) 927-2100, houle@almvmd(BITNET); Doug Lowndes, Oak Ridge National Laboretory, (615) 574-6306, FAX (615) 574-4143

SYMPOSIUM B: ELECTRONIC, OPTICAL AND DEVICE PROPERTIES OF LAYERED STRUCTURES John Hayes, Bellcore, (201) 758-2851, FAX (201) 758-9626; Mark S. Hybertsen, AT\&T Bell Laboratories, (201) 5823628, FAX (201) 582-3901; Eicke R. Weber, University of California, Berkeley, (415) 642-0205, FAX (415) 486-5933

SYMPOSIUM C: EVOWTION OF THIN FILM AND SURFACE MICRO STRUCTURE Carl V. Thompson, Massachusetts Institute of Technology, (617) 253-7652, FAX (617)-258-8539, CTHOMP@ @AF.MIT.EDU; Jeffrey Y. Tsao, Sandia National Laboratories, (505) 844-7092, FAX (505) 846-9709, JEFTSAO@SANDIA.GOV; David J. Srolovitz, University of Michigan, (313) 936-1740, FAX (313) 763-4788, SROL@DODO.ENGIN.UMICH.EDU

SYMPOSIUM D: ELECTRONIC PACKAGING MATERIALS SC1ENCE Edwin D. Lillie, Microelectronics \& Computer Technology Corporation, (512) 250-2715, FAX (512) 250-2893; Ralph J. Jaccodine, Lehigh University, (215) 758-4409, FAX (215) 758-4561; Paul Ho, IBM T.J. Watson Research Center, (914) 945-2007; FAX (914) 945-2141; Kenneth Jackson, University of Arizona, (602) 322-2981; FAX (602) 322-2993

SYMPOSIUM E: CHEMICAL PERSPECTIVES OF MICROELECTRONIC MATERIALS Lawrence H. Dubois, AT\&T Bell Laboratories, (201) 582-7920; FAX (201) 582-3958; Leonard V. Interrante, Rennselaer Polytechnic Institute, (518) 276-2644, FAX (518) 276-2636; Mihal E. Gross, AT\&T Bell Laboratories, (201) 582-4504, FAX (201) 582-2913; Klavs F. Jensen, Massachusetts Institute of Technology, (617) 253-4589, FAX (617) 253-9695

SYMPOSIUM F: KINETICS OF PHASE TRANSFORMATIONS Michael O. Thompson, Cornell University, (607) 255-4714, FAX (607) 255-2365; Michael J. Aziz, Harvard University, (617) 495-9884, FAX (617) 495-9837; G. Brian Stephenson, IBM T.J. Watson Research Center, (914) 945-3008, FAX (914) 945-2141; David Cherns, Bristol University, United Kingdom SYMPOSIUM G: CLSTERS AND CLSTER-ASSEMBLED MATERALS Robert S. Averback, University of llinois, (217) 333-4302, FAX (217) 244-2278; David L. Nelson, Office of Naval Research, (202) 696-4410, FAX (202) 696-5383; J. Bernholc, North Carolina State University, (919) 737 3126, FAX (919) 737-7331

SYMPOSIUM H: MATERIALS ISSUES IN APPLICATIONS OF CERAMIC SUPERCONDUCTORS Allen M. Goldman, University of Minnesota, (612) 624-6525, FAX (612) 624-4578; Julia M. Phillips, AT\&T Bell Laboratories, (201) 582-4428, FAX (201) 582-2521; Kenneth W. Lay, GE Corporate Research and Development Center, (518) 387-6147, FAX (518) 387-7495; Anthony C. Schaffhauser, Oak Ridge National Laboratory, (615) 574-4826, FAX (615) 574-6073

SYMPOSIUM I: MECHANICAL PROPERTIES OF POROUS AND CELWLAR MATERIALS Lorna J. Gibson, Massachusetts Institute of Technotogy, (617) 253-7107, FAX (617) 253-6044; David Green, Pennsylvania State University, (814) 863-2011, FAX (814) 865-2917, Karl Sieradzki, Johns Hopkins University, (301) 338-5409, FAX (301) 338-5293

SYMPOSIUM J: ADVANCES IN SURFACE AND THIN FIM DIFFRACTION Philip I. Cohen, University of Minnesota, (612) 625-5517, FAX (612) 625-4583; David J. Eaglesham, AT\&T Bell Laboratories, (201) 582-3768, FAX (201) 582-2121; Ting C. Huang, IBM Almaden Research Center, (408) 927-2375, FAX (408) 927-2100

SYMPOSIUM K: DEFECTS IN MATERIALS Paul D. Bristowe, Massachusetts Institute of Technology, (617) 253-3326, FAX (617) 253-8000; J. Emest Epperson, Argonne National Laboratory, (708) 972-4971 or 972-5546, FAX 
(708) 972-4163 or 972-3308; J.E. Griffith, AT\&T Bell Laboratories, (201) 582-5222, FAX (201) 582-2913; Z. Lilientat-Weber, Lawrence Berkeley Laboratory, (415) 486-6276, FAX (415) 486-4995

SYMPOSIUM L: SOLID STATE IONICS Gholam-Abbas Nazri, GM Research Laboratories, (313) 9860737, FAX (313) 986-2244; Robert A. Huggins, (415) 725-4110, FAX (415) 725-4034; Duward F. Shriver, Northwestern University, (708) 491-5655, FAX (708) 491-7713; Minko Balkanski, Université Pierre et Marie Curie, France, (1) 43-36-25-25, FAX (1) 43-25-77-07

SYMPOSIUM M: DYNAMICS IN SMALL CONFINING SYSTEMS J.M. Drake, Exxon Research \& Engineering Company, (201) 730-2848, FAX (201) 730-3042; R. Kopelman, University of Michigan, (313) 764-7541, FAX (313) 747-4865; J. Klafter, Tel Aviv University, Israel, 972-3-5450254, FAX 972-35413752

SYMPOSIUM N: COVALENT CERAMICS Gary S. Fischman, Alfred University, (607) 871-2284, FAX (607) 871-3469; Terry Aselage, Sandia National Laboratories, (505) 845-8027, FAX (505) 844-2974; Richard M. Spriggs, Alfred University, (607) 871-2486, FAX (607) 871-3469

SYMPOSIUM O: FIBER-REINFORCED CEMENTITIOUS MATERIALS Sidney Mindess, University of British Columbia, (604) 228-6413, FAX (604) 228-7006; Jan P. Skalny, W.R. Grace and Company, (301) 531-4597, FAX (301) 531-4367

SYMPOSIUM P: SCIENTIFIC BASIS FOR NUCLEAR WASTE MANAGEMENT XIV T. Abrajano, Jr., Argonne National Laboratory, (708) 972-4261, FAX (708) 972-5246; Lawrence H. Johnson, Whiteshell Nuclear Research Establishment, (204) 753-2311, FAX (204) 753-2455

SYMPOSIUM Q: HIGH TEMPERATURE ORDERED INTERMETALLIC ALLOYS LYman Johnson, G.E. Aircraft Engines, (513) 786-4353, FAX (513) 243-3250; David P. Pope, University of Pennsylvania, (215) 898-4825, FAX (215) 898-1130; James 0. Stiegler, Oak Ridge National Laboratory, (615) 574-4065, FAX (615) 574-7721

SYMPOSIUM R1: OPTICAL AND ELECTRICAL PROPERTIES OF POLYMERS John A. Emerson, AT\&T Bell Laboratories, (609) 639-2571, FAX (609) 639-2835; John M. Torkelson, Northwestern University, (708) 491-7449, FAX (708) 491-3728

SYMPOSIUM R2: STRUCTURE, RELAXATION AND PHYSICAL AGING OF GLASSY POLYMERS R. Joon Roo, University of Cincinnati, (513) 556-3117, FAX (513) 556-3626, INTERNET RROE@UCENG.UC.EDU; James M. O'Reilly, Eastman Kodak Company, (716) 477-4334, FAX (716) 722-2327, BITNET JMOREI@KODAK.COM; John Torkelson, Northwestem University, (708) 491-7449, FAX (708) 491-3728

SYMPOSIUM S: SYNTHESIS AND PROPERTIES OF NEW CATALYSTS: UTILIZATION OF NOVEL MATERIALS COMPONENTS AND SYNTHETIC TECHNIQUES Edward W. Corcoran, Jr., Exxon Research and Engineering Company, (201) 730-2465, FAX (201) 730-3042; Marc J. Ledoux, Université Louis Pasteur Strasbourg, France, (33) 88-416147, FAX (33) 88-607550; Jack R. Knox, Knox Consulting Company, (708) $357-3707$

SYMPOSIUM T: LONG-WAVELENGTH SEMICONDUCTOR DEVICES, MATERIALS AND PROCESSES Avishay Katz, AT\&T Bell Laboratories, (201) 582-2261, FAX (201) 582-4347; Robert M. Biefeld, Sandia National Laboratories, (505)844-1556, FAX (505) 844-3211; R.J. Malik, AT\&T Bell Laboratories, (201) 582-6580, FAX (201) 582-3901; Robert L. Gunshor, Purdue University, (317) 494-3509, FAX (317) 4946440

SYMPOSIUM U: ADVANCED TOMOGRAPHIC IMAGING METHODS FOR THE ANALYSIS OF MATERIALS Jerome L. Ackerman, Massachusetts General Hospital, (617) 726-3083, FAX (617) 7265819; William A. Ellingson, Argonne National Laboratory, (708) 972-5068, FAX (708) 972-4798

SYMPOSIUM V: MATERIALS SYNTHESIS BASED ON BIOLOGICAL PROCESSES Mark Alper, University of California, Berkeley, (415) 486-6581, FAX (415) 486-4995; Peter C. Rieke, Battelle Pacific Northwest Laboratory, (509) 375-2833, FAX (509) 375-2168; Richard Frankel, California Polytechnic State University, (805) 756-2467, FAX (805) 541-2040; Paul D. Calvert, University of Arizona, (602) 322 2960, FAX (602) 322-2993; David A. Tirrell, University of Massachusetts, (413) 545-2680, FAX (413) 545-0082

SYMPOSIUM W: SCALING IN DISORDERED MATERIALS James P. Stokes, Exxon Research and Engineering Company, (201) 730-2926, FAX (201) 730-3042; Mark O. Robbins, Johns Hopkins University, (301) 338-7204, FAX (301) 338-8260; Tom A. Witten, University of Chicago, (312) 702-0947, FAX (312) $702-5863$

SYMPOSIUM X: FRONTIERS OF MATERIALS RESEARCH Rustum Roy, The Ponnsylvania State University, (814) 865-3421, FAX (814) 865-2326

SYMPOSIUM Y: NANOSTRUCTURES: FABRICATION AND PHYSICS T.P. Smith III, IBM T.J. Watson Research Center, (914) 945-2809, FAX (914) 945-2141; Steven D. Berger, AT\&T Bell Laboratories, (201) 582-2484, FAX (201) 582-2685; Dieter Kern, IBM T.J. Watson Research Center, (914) 945-1147, FAX (914) 945-4013; Harold Craighead, Cornell University, (607) 255-8707, FAX (607) 255-7658

The Fall 1990 MRS Call for Papers can be obtained from the Materials Research Society, 9800 McKnight Road, Pittsburgh, PA 15237; Telephone (412) 367-3003; FAX (412) 367-4373. 


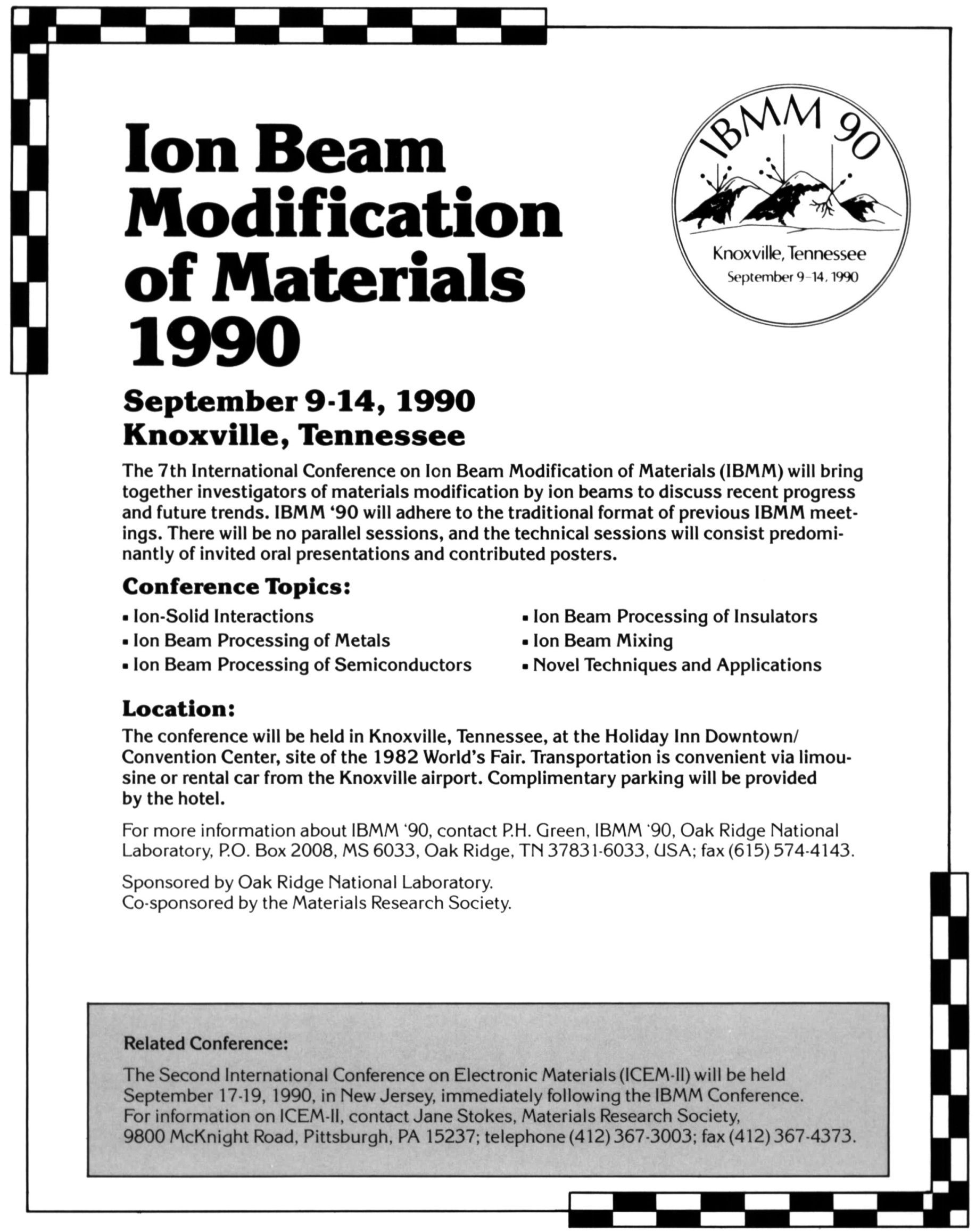




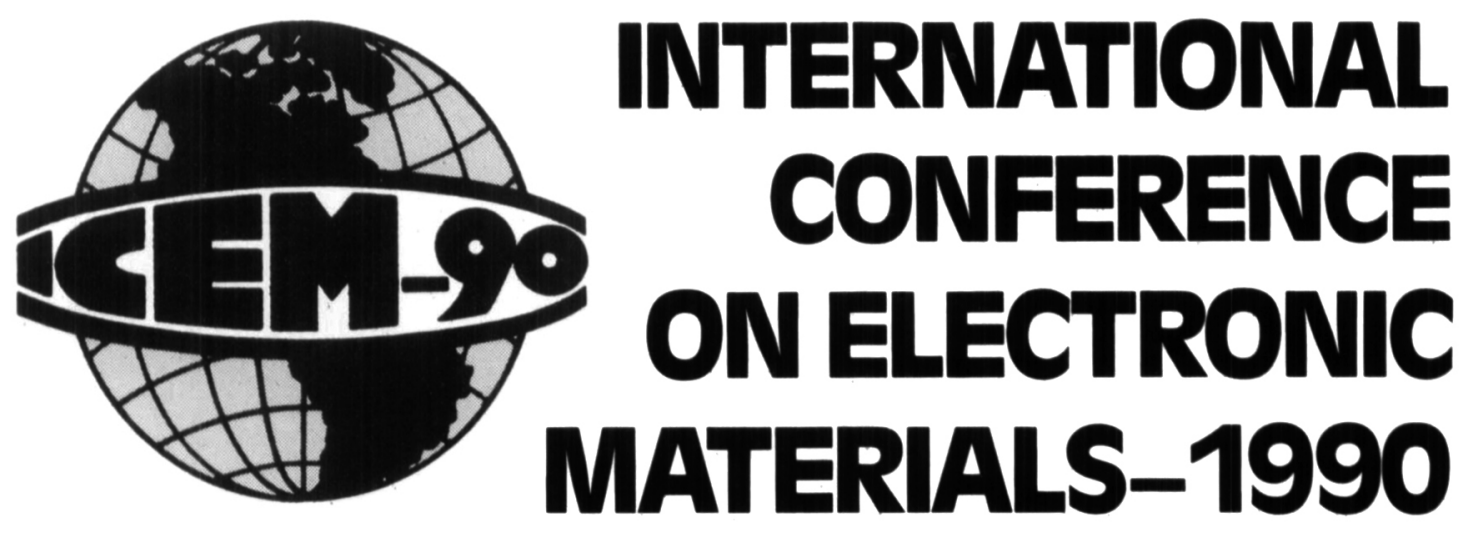

September 17-19, 1990 Newark, New Jersey, USA

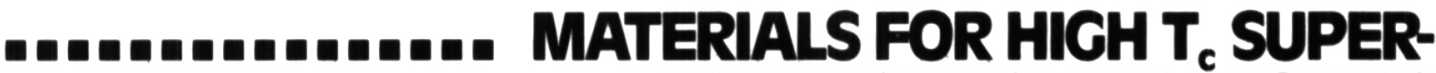
CONDUCTING ELECTRONICS

MATERIALS FOR OPTOELECTRONICS ADVANCED THIN FILM TECHNOLOCY DIAMOND FOR ELECTRONIC AND OPTICAL APPLICATIONS

EQUIPMENT EXHIBIT

For further information contact: ICEM-90

Materials Research Society 9800 Mcknight Road

Pittsburgh, PA 15237

Telephone (412) 367-3003 FAX (412) 367-4373

co-sponsored by:

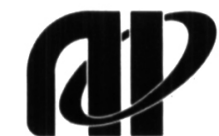

The Japan Society of Applied Physics

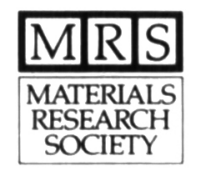

The Materials Research Society

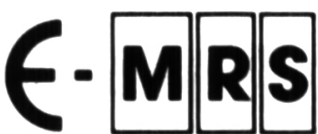

European Materials Research Society

CONFERENCE CHAIRS: Prof. R.P.H. Chang - Prof. Takuo Sugano - Dr. Van Tran Nguyen 